\title{
Massive obstetrics haemorrhage: our experience
}

\author{
Balasudha K*, Seetha Panicker
}

\begin{abstract}
Department of Obstetrics and Gynaecology, PSG Institute of Medical Sciences \& Research, Coimbatore-641004, Tamil Nadu, India
\end{abstract}

Received: 1 November 2013

Accepted: 13 November 2013

\author{
*Correspondence: \\ Dr. Balasudha K, \\ E-mail: balasudha@psgimsr.ac.in
}

(C) 2014 Balasudha $\mathrm{K}$ et al. This is an open-access article distributed under the terms of the Creative Commons Attribution Non-Commercial License, which permits unrestricted non-commercial use, distribution, and reproduction in any medium, provided the original work is properly cited.

\begin{abstract}
Background: The aim of the study was to analyze the clinical profile, treatment modalities and outcome of patients with massive obstetric haemorrhage.

Methods: All patients who delivered in the department of Obstetrics and Gynaecology PSG Institute of Medical Sciences, Coimbatore between Jan 2012 to Dec 2012 were analyzed. There were 2339 deliveries in this period. Of these there were 17 patients with serious obstetric haemorrhage who required blood transfusion giving an incidence of $0.73 \%$. All the patients who fulfilled the criteria of massive obstetric haemorrhage were analyzed.

Results: Past Of the 2339 deliveries from Jan 2012 to Dec 2012 there were 17 patients with serious haemorrhage. Out of these four patients who had massive obstetric haemorrhage are presented in this study.

Conclusions: Obstetric haemorrhage continues to be the leading cause of maternal mortality in India. Initial resuscitation with simultaneous identification of the cause and definitive treatment is important.
\end{abstract}

Keywords: Obstetric haemorrhage, Blood transfusion

\section{INTRODUCTION}

Obstetric haemorrhage remains a significant cause of maternal mortality and morbidity in spite of advances in medical and surgical management and blood transfusion facilities. WHO data indicates haemorrhage accounts for $35 \%$ of maternal deaths worldwide. ${ }^{1}$ Life threatening haemorrhage occurs as frequently as 6.6 per 1000 deliveries ${ }^{1}$. Massive obstetric haemorrhage is variably defined as: blood loss $>1500 \mathrm{ml}$; a decrease in haemoglobin $>4 \mathrm{gm} / \mathrm{dl}$; or acute transfusion requirement $>4$ units. $^{2-4}$ Obstetric haemorrhage is classified as antepartum (APH); bleeding occurring after 24 weeks gestation and before delivery, or postpartum (PPH). Postpartum haemorrhage can be primary (within 24 hours of delivery) or secondary ( 24 hours to six weeks after delivery). The management of obstetric haemorrhage is more challenging than haemorrhage in non-pregnant patients. Signs of hypovolaemia occurs relatively late because of physiological changes in pregnancy. The extent of intravascular volume deficit is not reflected by visual estimates of vaginal bleeding. Clear and timely communication between obstetric, anesthetic and haematology services is vital to ensure optimal maternal and fetal outcome. Interventions to evaluate and control bleeding should be relatively aggressive. ${ }^{5}$ The decision to perform a laparotomy or hysterectomy should be made when other method of haemostasis have failed and not delayed until control of maternal haemostasis and cardiovascular stability has been lost.
Aim
To analyze the clinical profile, treatment modalities and outcome of patients with massive obstetric haemorrhage.

\section{METHODS}
All patients who delivered in the department of Obstetrics and Gynaecology PSG Institute of Medical Sciences, 
Coimbatore between Jan 2012 to Dec 2012 were analyzed. This is a teaching hospital with referrals from nursing homes as well as from the surrounding districts. There were 2339 deliveries in this period. Of these there were 17 patients with serious obstetric haemorrhage who required blood transfusion giving an incidence of $0.73 \%$. Patients who required transfusion due to preexisting anaemia were excluded. All the patients who fulfilled the criteria of massive obstetric haemorrhage were analyzed.

\section{RESULTS}

Of the 2339 deliveries from Jan 2012 to Dec 2012 there were 17 patients with serious haemorrhage and the causes are shown in Table 1. Placenta accreta associated with placenta previa is a condition of increasing clinical significance. $^{6}$

- Of these there were four patients who had massive life threatening haemorrhage giving an incidence of $0.17 \%$

- The age and parity of these patients is shown in Table 2.

- Complications in the present and previous pregnancies are shown in Table 3.
Table 1: Analysis of cases of obstetrics haemorrhage.

\begin{tabular}{|ll|}
\hline Causes of obstetric haemorrhage & $\begin{array}{l}\text { No. of } \\
\text { cases }\end{array}$ \\
\hline Placenta acreta - Caesarean hysterectomy done & 3 \\
\hline B Lynch suture during LSCS for atonic PPH & 2 \\
\hline Rupture uterus - laparotomy and rent closure & 1 \\
\hline Antepartum haemorrhage & 2 \\
\hline Retained placenta & 2 \\
\hline $\begin{array}{l}\text { Portal hypertension with PIH with } \\
\text { decompensated liver disease }\end{array}$ & 1 \\
\hline Atonic PPH & 3 \\
\hline Jaundice & 2 \\
\hline Amniotic fluid embolism & 1 \\
\hline Total Cases & $\mathbf{1 7}$ \\
\hline
\end{tabular}

Table 2: Age and parity.

\begin{tabular}{|c|c|c|c|c|}
\hline Details & Case 1 & Case 2 & Case 3 & Case 4 \\
\hline Age & 31 years & 24 years & 32 years & 27 years \\
\hline $\begin{array}{l}\text { Parity \& } \\
\text { Gestatio } \\
\text { nal age }\end{array}$ & $\begin{array}{l}\text { G1 with } \\
37 \text { weeks }\end{array}$ & $\begin{array}{l}\text { G2 P1 } \\
\text { L1 with } \\
21 \text { weeks } \\
+1 \text { day }\end{array}$ & $\begin{array}{l}\text { G3 P1 } \\
\text { L1 A1 } \\
\text { with } 26 \\
\text { weeks }\end{array}$ & $\begin{array}{l}\text { G2 P1 L0 } \\
\text { with } 33 \\
\text { weeks } 4 \\
\text { days }\end{array}$ \\
\hline
\end{tabular}

Table 3: Complications in the present and previous pregnancies

\begin{tabular}{|lllll|}
\hline Details & Case 1 & Case 2 & Case 3 & Case 4 \\
Past obstetric history & $\begin{array}{l}\text { Married since 10 } \\
\text { years. IUI } \\
\text { conception. }\end{array}$ & $\begin{array}{l}\text { I pregnancy: acute } \\
\text { inversion of uterus } \\
\text { in III stage }\end{array}$ & $\begin{array}{l}\text { Previous LSCS. } \\
\text { Previous medical } \\
\text { abortion with profuse } \\
\text { bleeding PV and shock. }\end{array}$ & $\begin{array}{l}\text { Previous LSCS. } \\
\text { Baby died at 2 years of } \\
\text { age. }\end{array}$ \\
\hline $\begin{array}{l}\text { Complications in } \\
\text { current pregnancy }\end{array}$ & $\begin{array}{l}\text { GDM on insulin. } \\
\text { Mild pre-eclampsia }\end{array}$ & $\begin{array}{l}\text { Bleeding P/V I } \\
\text { trimester. }\end{array}$ & PPROM & $\begin{array}{l}\text { Absent fetal movements } \\
\text { for 2 days. USG: FH } \\
\text { absent. }\end{array}$ \\
\hline
\end{tabular}

\section{Course of labour/abortion}

\section{Case 1}

Primi gravid with 37 weeks of gestation with GDM on insulin. Labour was induced by PG E2 gel and oxytocin. .Immediately after delivery the patient developed breathlessness and disorientation and massive DIC. Patient was treated medically and transfused with more than 10 units of blood and blood products. Due to persistent haemorrhage inspite of medical treatment patient was taken up for obstetric hysterectomy. In the post op period patient died of massive DIC probably due to amniotic fluid embolism.

\section{Case 2}

G2 P1 L1 with 21 weeks +1 day gestation was admitted with PPROM and profuse bleeding per vaginum. USG
Showed anhydramnios and placenta covering the os Due to continuing haemorrhage patient was posted for hysterotomy. Placenta was adherent to lower uterine segment during hysterotomy and it was removed piecemeal. There was active bleeding from the lower uterine segment. Medical measures as well as conservative surgical methods were tried. Due to continuing bleeding proceeded with hysterectomy. More than 30 units of blood and blood products were transfused.

\section{Case 3}

G3 P1 L1 A1 with 26 weeks of gestation with previous LSCS. Admitted with pain abdomen and draining PV. Ultrasound showed Single live intra uterine fetus of 26 weeks gestation, estimated fetal weight $884 \mathrm{gm}$. Placenta was anterior. Amniotic fluid grossly reduced with evidence of chorioamnionitis. Patient developed 
spontaneous uterine contractions and expelled a still born fetus. Placenta was retained and there was massive III stage haemorrhage. Manual removal of placenta done under GA. Hemoglobin dropped to $7 \mathrm{gm} / \mathrm{dl}$. Blood loss more than $1500 \mathrm{ml} .8$ units of blood products transfused.

\section{Case 4}

G2 P1 L0 with 33 weeks + 4 days gestation with previous LSCS admitted with absent fetal movements.

Ultrasound confirmed intrauterine death with Spalding's sign. Liquor grossly reduced. Labour was induced and she delivered a dead born fetus. Patient had massive III stage haemorrhage with retained placenta and she was shifted to the operation theatre for manual removal of placenta under GA. Placenta was adherent with velamentous insertion of cord. Uterus was atonic after placental removal. USG showed intact uterus. Patient was treated with oxytocics and 22 size Foley's catheter inserted into the uterus and bulb distended with $100 \mathrm{ml}$ of saline water which was removed after 24 hours. 6 units of blood products transfused.

\section{Summary of treatment}

Table 4: Oxytocics used.

\begin{tabular}{|lll|ll|}
\hline $\begin{array}{l}\text { Oxytocics } \\
\text { used }\end{array}$ & Case 1 & Case 2 & Case 3 & Case 4 \\
\hline $\begin{array}{l}\text { Oxytocin } \\
\text { (units) }\end{array}$ & $10+20+20$ & 20 & $20+20$ & $20+10$ \\
\hline $\begin{array}{l}\text { Ergometrine } \\
\text { (Amp) }\end{array}$ & 3 & 3 & 1 & 1 \\
\hline PGF2 $\alpha$ & 4 & 5 & 1 & 1 \\
\hline Misoprostol & 800 & $600 \mu \mathrm{g}$ & $800 \mu \mathrm{g}$ & $600 \mu \mathrm{g}$ \\
\hline
\end{tabular}

Table 5: Summary of investigations of all cases.

\begin{tabular}{|lllll|}
\hline $\begin{array}{l}\text { Investigati } \\
\text { ons }\end{array}$ & Case $\mathbf{1}$ & Case 2 & Case 3 & Case 4 \\
\hline $\mathrm{Hb}$ & $7 \mathrm{gm} / \mathrm{dl}$ & $4.8 \mathrm{gm} / \mathrm{dl}$ & $7.1 \mathrm{gm} / \mathrm{dl}$ & $8.1 \mathrm{gm} / \mathrm{dl}$ \\
\hline Platelets & $1,68,000$ & $1,42,000$ & $1,40,000$ & $1,62,000$ \\
\hline PT & $26.6 \mathrm{sec}$ & $>150 \mathrm{sec}$ & $15.9 \mathrm{sec}$ & $19.9 \mathrm{sec}$ \\
$\mathrm{INR}$ & 2.55 & $>23$ & 1.28 & 1.71 \\
APTT & $71.8 \mathrm{sec}$ & & $24.7 \mathrm{sec}$ & $42.4 \mathrm{sec}$ \\
\hline Fibrinogen & 69 & $<43$ & 250 & 127 \\
& $\mathrm{mg} / \mathrm{dl}$ & $\mathrm{mg} / \mathrm{dl}$ & $\mathrm{mg} / \mathrm{dl}$ & $\mathrm{mg} / \mathrm{dl}$ \\
\hline Hb & $7 \mathrm{gm} / \mathrm{dl}$ & $4.8 \mathrm{gm} / \mathrm{dl}$ & $7.1 \mathrm{gm} / \mathrm{dl}$ & $8.1 \mathrm{gm} / \mathrm{dl}$ \\
\hline
\end{tabular}

Table 6: Summary of serial investigations of case 2.

\begin{tabular}{|llllll|}
\hline Investigations & Day $\mathbf{1}$ & $\mathbf{6 ~ h r s ~ l a t e r}$ & Day 2 & Day 3 & Day 5 \\
\hline $\mathrm{Hb}$ & $5.9 \mathrm{gm} / \mathrm{dl}$ & $4.8 \mathrm{gm} / \mathrm{dl}$ & $9.7 \mathrm{gm} / \mathrm{dl}$ & - & $11.5 \mathrm{gm} / \mathrm{dl}$ \\
\hline Platelets & $2,69,000$ & $1,42,000$ & 44,000 & 43,000 & 46,000 \\
\hline $\mathrm{PT}$ & $13.9 \mathrm{sec}$ & $>150 \mathrm{sec}$ & $23.3 \mathrm{sec}$ & $20.4 \mathrm{sec}$ & 21.8 \\
$\mathrm{INR}$ & $1.09 \mathrm{sec}$ & $>23$ & 2.08 & 1.76 & 1.92 \\
APTT & - & $>150 \mathrm{sec}$ & $37.8 \mathrm{sec}$ & - & - \\
\hline Fibrinogen & - & $<43 \mathrm{mg} / \mathrm{dl}$ & $142 \mathrm{mg} / \mathrm{dl}$ & - & - \\
\hline
\end{tabular}

Table 8: Surgical measures.

\begin{tabular}{|c|c|c|c|c|}
\hline Procedure & Case 1 & Case 2 & Case 3 & Case 4 \\
\hline $\begin{array}{l}\text { Surgical } \\
\text { procedures }\end{array}$ & $\begin{array}{l}\text { - B-Lynch Suture } \\
\text { - Stepwise } \\
\text { devascularisation } \\
\text { - Hysterectomy done }\end{array}$ & $\begin{array}{l}\text { - B-Lynch Suture } \\
\text { - Stepwise } \\
\text { devascularisation } \\
\text { - Hysterectomy done }\end{array}$ & $\begin{array}{l}\text { - Manual removal } \\
\text { of placenta } \\
\text { - Uterine } \\
\text { exploration done. }\end{array}$ & $\begin{array}{l}\text { - Manual removal of placenta } \\
\text { - Foley's catheter } 22 \text { size with } \\
100 \mathrm{ml} \text { saline kept in utero for } \\
24 \mathrm{hrs}\end{array}$ \\
\hline
\end{tabular}

Table 7: Blood \& blood products used.

\begin{tabular}{|lllll|}
$\begin{array}{l}\text { Blood products } \\
\text { used (units) }\end{array}$ & Case $\mathbf{1}$ & Case 2 & Case 3 & Case 4 \\
\hline Packed cells & 7 & 8 & 4 & 2 \\
\hline FFP & 11 & 8 & 4 & 4 \\
\hline Platelets & 4 & 8 & 2 & 2 \\
\hline Cryo & 10 & 4 & - & - \\
\hline
\end{tabular}

\section{DISCUSSION}

Of the 17 patients who presented with major obstetric haemorrhage four had massive life threatening haemorrhage. When analyzed, the clinical profile of these patients was variable. The age group of these patients was between $24 \& 32$ years. Only one was a primigravida, all the others were multis. Regarding pregnancy complications there was one patient with gestational diabetes and mild preeclampsia, one with PPROM and one with intra-uterine death. Complications in the 
previous pregnancy were also significant. One patient had acute puerperal inversion of uterus in the previous pregnancy which was treated by manual replacement and blood transfusion. Another patient's previous pregnancy was delivered by caesarean section following which she had a medical abortion and then presented with profuse bleeding with shock.

\section{Lessons learned}

After delivery blood loss and other clinical parameters should be closely monitored. ${ }^{7}$ The initial resuscitation should go hand in hand with diagnosis and definitive treatment. The initial resuscitation is with isotonic crystalloid solution. ${ }^{8}$ In most blood banks, a full cross match takes 45 minutes to 1 hour. Hence previously cross matched blood is extremely important in high risk patients. In an emergency situation ' $\mathrm{O}$ ' negative blood can be obtained in 10 to 15 minutes. It is important to call for help..$^{-11}$ The senior obstetrician, anesthetist, pediatrician if required as well as senior nursing staff should be alerted as soon as possible. Blood bank, laboratory as well as the operation theater should be alerted. There should be enough people to communicate among the different specialties as well as to collect reports, blood and blood products. ${ }^{2}$ Protocols for the management of APH, PPH and other emergencies should be familiar to all staff in the labour ward. Record of the patient's vital signs, drugs administered, investigations requested, blood and blood products administered should be maintained in a systematic and meticulous manner as many people would be involved in the care of the patient as shown in the tables of investigations \& treatment summary. Surgical treatment like internal iliac artery ligation and hysterectomy should be considered if the haemorrhage does not respond to conservative measures and should not be delayed until the patient is in irreversible shock.

\section{CONCLUSIONS}

Obstetric haemorrhage continues to be the leading cause of maternal mortality. ${ }^{12}$ Initial resuscitation with simultaneous identification of the cause and definitive treatment is important. Ready availability of blood and blood products may be life saving in many cases. Early resort to surgical methods is advisable rather than waiting till the shock is irreversible.

\section{ACKNOWLEDGEMENTS}

We gratefully acknowledge the help of our department colleagues and nursing staffs of labour ward.

\section{Funding: No funding sources}

Conflict of interest: None declared

Ethical approval: The study was approved by the institutional ethics committee

\section{REFERENCES}

1. B. Kloster MD and J Gorlin MD. Obstetric Hemorrhage. Blood bulletin. 15th St. NW, Washington: Publication Committee Chair; 2012 December: 1-2.

2. Amelia Banks, BSc MBBS MRCP FRCA, Specialist Registrar in Anaesthesia. Andrew Norris, MB ChB FRCA, Consultant Anaesthetist. Massive haemorrhage in pregnancy. Oxford Journals Medicine. BJA: CEACCP. Contin Educ Anaesth Crit Care Pain. 2005 December;5(6):195-8.

3. Clinical guidelines for the management of a major obstetric haemorrhage and escalation to massive obstetric haemorrhage and proforma. Royal Cornwall Hospitals. NHS Trust. 2013 June. Review 2016 June. Available

at: http://www.rcht.nhs.uk/DocumentsLibrary/RoyalCor nwallHospitalsTrust/Clinical/MidwiferyAndObstetri cs/MassiveObstetricHaemorrhageGuidelineForTheM anagementOf.pdf.

4. Rajashree Chavan \& M. Y. Latoo. Recent advances in the management of major obstetric haemorrhage. British Journal of Medical Practitioners. 2013Mar;6(1):a(604).

5. Lumaan Sheikh, Nadeem F. Zuberi, Rubab Riaz, et al. Massive Primary Postpartum Haemorrhage: Setting Up Standards of Care. J Pak Med Assoc. 2006 January;56(1):26-31.

6. S Chowdhury, M Rashid. Successful Management of Massive Obstetric. Haemorrhage due to Placenta Previa/Accreta - A Case Report. Journal of Bangladesh College of Physicians and Surgeons. 2011 January;29(1):46-8.

7. A. Metin Gülmezoglu, João Paulo Souza, Doris Chou, et al. WHO guidelines for the management of postpartum haemorrhage and retained placenta. 20 Avenue Appia. Geneva, Switzerland: WHO Press; 2009:5-12.

8. Sheila Macphail, Kate Talks. Massive post-partum haemorrhage and management of disseminated intravascular coagulation. Current Obstetrics \& Gynaecology. 2004;14:123-31.

9. $\mathrm{N}$ du Plessis. Obstetric haemorrhage and the use of blood and blood products. O\&G Forum. 2013May;23:15-21.

10. A. Wise, V. Clark. Best Practice \& Research Clinical Obstetrics and Gynaecology. 2010;24:353-65.

11. Suzy Baldwin, Matt Rucklidge. Management of obstetric haemorrhage. Update in Anesthesia. 2009 Dec;25(2):42-9.

12. Rudra A, et al. Management of obstetric hemorrhage. Eur J Anesth. 2010;20(4)2010:499-508.

DOI: $10.5455 / 2320-1770 . i j r \operatorname{cog} 20140307$

Cite this article as: Balasudha $\mathrm{K}$, Panicker S.

Massive obstetrics haemorrhage: our experience.

Int J Reprod Contracept Obstet Gynecol 2014;3:40-

3 . 